\title{
Correction to: Variations on the nest architecture in the rufous-fronted thornbird complex, Phacellodomus rufifrons (Aves: Furnariidae)
}

\author{
Fabio Schunck ${ }^{1}$ (1) $\cdot$ Vítor Q. Piacentini ${ }^{1,2}$ (D)
}

Published online: 20 September 2021

(c) Sociedade Brasileira de Ornitologia 2021

Correction to: Ornithology Research (2021)

https://doi.org/10.1007/s43388-021-00062-1

This correction is to update Table 1 and remove the commas inserted into the codes in the first column.

The original article has been corrected.

The original article can be found online at https://doi.org/10.1007/ s43388-021-00062-1.

Fabio Schunck

fabio_schunck@yahoo.com.br

1 Comitê Brasileiro de Registros Ornitológicos - CBRO, Av.

Eugênio Bartolomai, 386, São Paulo, SP 04785-040, Brazil

2 Departamento de Biologia e Zoologia \& PPG Zoologia Instituto de Biociências, Universidade Federal de Mato Grosso, Mato Grosso, Cuiabá, Brazil 